\title{
Duisenberg and Trichet: Measures of their Degree of Conservatism
}

\author{
Ibrahima Diouf \\ Dominique Pépin *
}

\section{$1 \quad$ Introduction}

The management of a central bank is one of the most prestigious positions of economic responsibility. It confers important powers and a certain authority. However, central bankers remain dependent on the institutional environment in which they make decisions. In western democracies, although most central banks are now independent, the government preserves its prerogatives in the nomination and revocation of their presidents.

The European Central Bank (ECB) is at the heart of the European Economic and Monetary Union (EMU) and its President holds important powers. He chairs the Governing Council (in charge of the formulation of monetary policy), the Executive Board (in charge of the implementation of monetary policy) and the General Council (gathering the 27 national Governors of Central Banks in the Union). His voice is decisive in the case of split votes in the Governing Council and Executive Board. He represents the ECB to the outside world, and he is invited to attend meetings of the European Council during deliberations on matters relating to the objectives and missions of the European System of Central Banks (ESCB).

The ECB is politically and economically independent (Article 20 of the Statutes of the ECB). The President, Vice-President and other members of the Executive Board are appointed by unanimous decision by the Heads of States or Governments belonging to the Monetary Union, on the

CRIEF, Université de Poitiers, UFR Sciences Économiques, 93 avenue du Recteur Pineau, 86000 Poitiers, France. Tél. +33 (0)5 494541 53, ibrahima.diouf@univ-poitiers.fr (auteur de contact), dominique.pepin @ univ-poitiers.fr. 
recommendation of the Council of the European Union Finance Ministers (Ecofin).

In November 2003, Jean-Claude Trichet (former Governor of the French Central Bank) succeeded Willem F. (Wim) Duisenberg (former Governor of Netherlands' Central Bank) as President of the ECB. In fact, their appointment resulted from political compromises between the countries of the single currency (the euro). The debate revolves around the consequences of the conservatism of the President's monetary policy. Depending on the degree of his conservatism, the Central Bank will give differing degrees of priority to monetary policy.

Statutorily, the ECB is mainly concerned with inflation ${ }^{1}$. But, in the court of public opinion, its President is also responsible for economic prosperity in the Euro area (growth, purchasing power etc.). His appointment clearly reflects a choice in the balance between inflation and growth. Many Northern European countries are less concerned with economic growth than with price stability, and it is in their interest to appoint a conservative President. Duisenberg's appointment seems to accord with their wishes. Trichet's appointment as his successor appears to be an attempt to reassure the Latin countries (France, Italy, Spain, Belgium), who are more concerned about economic growth and employment. Those different attitudes towards the monetary policy objectives result from the two models of Central Banks in Europe, characterized by different degrees of institutional conservatism.

However, there may be a difference between the expectations based on theoretical, political or partisan presuppositions and Central Bankers' real behavior. Therefore, a measure of their degree of conservatism may, retrospectively, be instructive. Concretely, did they act according to their reputation? Why does Trichet seem less conservative than Duisenberg? Has the change in the ECB Presidency changed the formulation of monetary policy to a less aggressive strategy?

This paper is organized as follows. The first section introduces the two main Central Bank models in Europe, and their influence on the appointment of the ECB's President. The second section, on the basis of the New Keynesian canonical model, develops a measure of the degree of conservatism of the Central Bank President. This measure appears to make a considerable contribution. Although there are sophisticated econometric models of the European monetary economy, there are no simple statistics summarizing the Central banker's past action. The third section presents the application of such a measure to the comparison of Duisenberg's and Trichet's Presidencies by considering the outcomes which are known to date.

1 According to Article 105 of the consolidated version of the Treaty on EMU, the ECB's primary objective is to maintain price stability in the euro-zone. Employment and growth targets are not explicitly excluded, but the ECB cannot pursue these goals without damage to its primary objective. 


\section{Two models of Central Banks}

As President of the ECB, why should France's candidate, Jean-Claude Trichet, be less conservative than the Dutchman, Wim Duisenberg? This presumption appears to be founded on the idea that, on the one hand, candidates are depositaries for institutional conservatism and, on the other hand, they have their own preferences on inflation.

There is a conservatism related to the institutional framework within which monetary policy is formulated and implemented. Indeed, the characteristics of the institutional environment for monetary-policy decisions influence their efficiency. For example, many studies have established that independent Central Banks generally obtain better results in the fight against inflation than those which are not independent (Bade and Parkin, 1985, Masciandaro and Tabellini, 1988). Furthermore, in Europe, different countries have different histories and monetary cultures ${ }^{2}$. This results in relative differences in the aversion to inflation among EMU members (Hayo, 1998). Thus, before the introduction of the euro, Europeans were organized around two Central Bank models: on the one hand, a model grouping the countries (such as Germany and other countries of Northern Europe) where price stability is the fundamental objective of monetary policy, its efficiency being guaranteed by the Central Bank's independence; and on the other hand, a model around the countries (such as Belgium, France, Italy, Spain) which consider the Central Bank to be responsible for both price stability and growth and employment.

These models correspond to different levels of institutional conservatism, the first being more conservative than the second ${ }^{3}$. Before the introduction of the euro, the reference for institutions in search for credibility was not the Bank of France or the Bank of Italy, but the Bundesbank and the Nederlandsche Bank. This reputation was based on a strong aversion to inflation, which was consolidated during the 1970s' wave of inflation and that resulting from German reunification (1990-1992). As shown in Table 1, for a long time monetary policies in Germany and the Netherlands focused on price stability and produced mean levels of inflation generally lower than

2 Some authors, such as Gordon (1975), suggest the existence of a collective memory "in which the experience of the Great Depression still weighs heavily, just as the relatively weaker full-employment commitment and stronger anti-inflation commitment in Germany must reflect memories of the hyperinflation" (Gordon, 1975, p. 828).

3 This argument is supported by several factors, for instance, the conditions suggested by the Germans (independence of national Central Banks, secure tenure for governors during their term, etc.), which are laid out in the Delors' Report (1989) leading to monetary union; the conditions in the Stability Pact; the French proposal to create an "economic government" in opposition to the power of the ECB; the simultaneous appointment of the first President and his successor; and Germany's pressure for Jürgen Stark to succeed Otmar Issing's as the ECB's chief economist. It is still relevant in explaining the divergent attitudes of German and French political leaders towards the ECB: the Germans rebutting any questioning of its independence, while the French (whatever the ruling party) criticize it repeatedly. 
those of countries, like France, which participated in the European Monetary System. In the process of monetary unification, countries using the second model simply pegged their currencies' parity to the deutschmark. This allowed them to benefit from a reduction in the difference between their interest rates and Germany's, which produced high levels of confidence in their currencies on the markets.

\begin{tabular}{|l|c|c|c|c|c|}
\hline & $\mathbf{1 9 7 3 - 7 8}$ & $\mathbf{1 9 7 9 - 8 3}$ & $\mathbf{1 9 8 4 - 8 8}$ & $\mathbf{1 9 8 9 - 9 3}$ & $\mathbf{1 9 9 4 - 9 8}$ \\
\hline Germany & 5.13 & 4.9 & 1.12 & 3.72 & 1.74 \\
\hline Netherlands & 7.91 & 5.20 & 1.14 & 2.52 & 2.18 \\
\hline France & 10.35 & 11.84 & 4.40 & 2.96 & 1.50 \\
\hline
\end{tabular}

Table 1: Average inflation rates

Annual inflation rates are calculated on the basis of the consumer price index. Source: OECD $(1989,1995,2000)$.

When in charge of their respective national Central Bank, Duisenberg and Trichet followed rather similar monetary policies. The Nederlandsche Bank's monetary policy, under Duisenberg, aimed to contain monetary expansion and to maintain the florin/mark exchange rate at the desired level ${ }^{4}$. The Netherlands' inflation rate being higher than Germany's, its short- and longterm interest rates were maintained above German rates. This monetary policy made the florin one of the most popular currencies in Europe ${ }^{5}$. Within the European Monetary System, the Dutch currency was considered, rightly, as a strong currency (i.e. regularly appreciating in value).

Jean-Claude Trichet took over the Bank of France in a context of deep reform of its institutional framework, the Monetary Policy Council being instructed to formulate the monetary policy independently (laws of August 4 and December 31, 1993). This direction fell under the process of the Economic and Monetary Union, with the objective of annual price increases of less than $2 \%$. The new Governor was the principal craftsman of the policy of a strong French franc. The goal was the disappearance of inflation in order to achieve a low interest rate in the long-term. The concrete justification of this policy is a curve representing the comparative development of American and French long-term rates: from 1914 to 1995, they were higher in France. In July 1981, in a full Keynesian stimulus plan, the rates were 17\% in France, against 13.4\% in the United States. From 1995, the French interest rate became lower than the American one. But, in November 2003,

4 Germany had a good anti-inflation record and was the Netherlands' main trading partner (1/3 of its foreign trade). In 1993, a bilateral agreement between the two countries limited the margins of fluctuation between their currencies to $2.25 \%$, compared to plus or minus $15 \%$ between all the EMS currencies.

5 According to Berthelot (1997), Duisenberg made the florin a stronger currency than the mark. 
when Trichet left the Bank of France for the Presidency of the ECB, inflation in France (measured by the growth of the harmonized consumer price index) was at $2.4 \%$, against $2 \%$ for the whole of the euro area.

These developments lead to the observation that, under Duisenberg and Trichet's leadership, both the Nederlandsche Bank and the Bank of France began to implement monetary policies giving priority to price stability. They showed appreciable success on the inflation front. However, over a long period, the Nederlandsche Bank achieved better results (Table 1). Such a finding is not only due to its earlier conversion to monetary orthodoxy, but also to its greater proximity with the Bundesbank. The Netherlands took advantage of a more rooted institutional conservatism in the competition for the presidency of the ECB. Its candidate won the unanimous support of his peers, governors of the national Central Banks within the European Union.

To general surprise, in the middle of 1998, France decided to introduce its own candidate for the post of President. After negotiations, it was agreed that Duisenberg and Trichet would share the position. Duisenberg was formally appointed first President of the ECB by the Summit of Heads of State and Government, in Brussels in May 1998, with an unwritten commitment to resign mid-term in favor of Trichet ${ }^{6}$. Meanwhile, the Deputy Governor of the Bank of France, Christian Noyer, was appointed as Vice-President of the ECB. These provisions and the toughness of the negotiations ${ }^{7}$ reveal that the concessions on institutional conservatism (including the term of the first President) were not sufficient to reassure the proponents of less monetary orthodoxy. The argument of conservatism relating to the personality of the candidates stems from this.

Basically the idea is that, when Central Banks are independent, their performance on inflation partly depends on the personal preferences of those in charge of monetary policy. The politico-economic analysis establishes that these preferences are related to ideological or political options, the right hav-

6 This compromise, obtained despite underlying disagreements, contradicts the Maastricht Treaty, which provides for an eight year term for the ECB President in order to guarantee his independence. To preserve the appearance of conformity with the Treaty, Duisenberg was appointed for a full term, but declared at once (while affirming that the initiative for these remarks came from him), that, given his age, he would not complete the term. On several occasions thereafter, he was to stress that the decision on his term was his sole decision. His position won the support of Jacques Santer (Chair of the European Commission), Hans Tietmeyer (Chairman of the Bundesbank) and Cristina Randzio-Lath (Chair of the Committee on Economic and Monetary Affairs of the European Parliament). In the French scenario, Duisenberg's resignation was to occur at the end of 4 years (i.e. in 2002) allowing Trichet to have a full 8-year term. However, because of his involvement in the Crédit Lyonnais affair, Trichet only became the ECB President in 2003 after his acquittal.

7 Both the Netherlands and France threatened to use their veto in the event of the failure of their candidate. No doubt the political context played a part in the intransigence of the negotiators: in the Netherlands (under the leadership of Prime Minister Wim Kok) and Germany (under the leadership of Chancellor Helmut Kohl) the ruling parties were ahead in legislative elections, while France was in a period of political cohabitation (between Jacques Chirac and Lionel Jospin). 
ing, on average, a greater aversion to inflation than the left. In fact, these preferences depend on many factors, including: public opinion as expressed in the media (Haan, Sturm and Maier, 2002, Knaap and Maier, 2002, Bezoen and Maier 2004) or in opinion polls (Vaubel, 2003); the specific demands of lobbies (Havrilesky, 1990); partisan affiliations (Hibbs, 1977); trends in government strategy (Aubin and Lafay 1995); the educational and/or professional backgrounds of the central bankers (Göhlmann and Vaubel, 2005).

In negotiations to appoint the first President of the ECB, the argument of personal conservatism allows us to understand the active support of the German government and the Bundesbank (particularly, its President Hans Tietmeyer) for Wim Duisenberg, whose application is conceived and presented, in Germany, as a pledge of monetary orthodoxy ${ }^{8}$. Moreover, the press at the time was not mistaken when, on the basis of a plea by the President of Nederlandsche Bank (Arnout Welling), it stressed that "more than the Dutch State's candidate, Mr. Duisenberg is that of Bundesbank" (Odent, 1998). On the other hand, the French candidature initially caused strong reservations, even some hostility. It came from, in particular, the influential English-language economic media (especially the Financial Times) in which the Governor of the Bank of France was "judged too etatist and colbertist to guarantee the independence of the single currency" (Lichfield, 2003). Thus, the Financial Times wrote in 1997 that his appointment to head the ECB would strike a "severe blow to the legitimacy" of the institution: "The basic problem is not to know if Mr. Trichet is a suitable candidate, but if it's reasonable to entrust him this station" (Financial Times quoted by Quatremer (2008)). Of course, those reproaches do not relate to Trichet' skills, but primarily to his degree of orthodoxy ${ }^{9}$.

Personal conservatism is linked to the central bankers' personal preferences for price stability (Frey and Schneider, 1981). As shown by economic analyses of bureaucracy, these preferences affect the outcomes of monetary policy (Toma and Toma, 1986) ${ }^{10}$. Göhlmann and Vaubel (2005) evoke the educational and/or professional background of the central bankers as factors likely to determine these preferences.

The ability to understand macroeconomic mechanisms and the principles of economic policy do indeed depend on academic training. A priori, as a central banker, an economist has an advantage, which reinforces a natural tendency to privilege his or her own objectives (Acheson and Chant, 1973). With regard to inflation, these preferences are not obvious, because

8 This support was given, it seems, despite a tacit agreement made with France that the ECB's headquarters would be in Frankfurt, and its presidency entrusted to a French national.

9 Trichet, who was at that time manager of the French Treasury, reportedly remained silent on the location of the ECB in Germany or in the Netherlands (Quatremer and Klau, 1999).

10 Economic analyses of bureaucracy have established a difference between the bureaucracy's objectives and the bureaucrats' motivations (Downs, 1967; Vaubel, 1997). For central banks this means that central bankers (bureaucrats) may have different targets than their official aims. 
they can be influenced by the nature of their education (Keynesian, monetarist) and by their teachers' political choices (left or right). Central bankers without an economic education, and therefore with a more limited understanding of monetary mechanisms, may be more receptive to the pressures and demands of the government which appointed them. A training orientated towards business (lawyer, manager, engineer) probably leads to a strong aversion to inflation. The consequences of inflation are an obstacle to the development of business, which may explain the traditional support of employers for the conservative political parties more disposed towards fighting inflation (Hibbs, 1977).

Professional experience may generate personal loyalties towards specific interest groups: a political party, a branch of industry, a bureaucracy etc. Thus, former bankers probably have, on average, a stronger aversion to inflation than former politicians or public servants. This difference can be explained by many factors, such as preference for a redistributive policy, reduction of the real national debt through inflation, or giving the economy a stimulus through unexpected inflation. A former career in the private sector (management, financial and banking sector etc.) can affect the independence of the central banker, as in the case of the non-renewal of his mandate, he would expect to be able to find an attractive alternative job. Accordingly, central bankers who were previously Central Bank staff, insurance executives, bankers, businessmen, or public servants can be expected to have, on average, a significantly stronger aversion to inflation than former politicians or trade unionists.

The two candidates for the Presidency of the ECB have important similarities in their career. Both had been central bankers, public servants, and employees in the private sector. As a central bankers, Duisenberg had directed the Bank of the Netherlands for 15 years (from 1982 to 1997), and Trichet the Bank of France for 10 years (from 1993 to 2003). As public servants Duisenberg had taught at universities (Groningue, 1961-1965; Amsterdam, 1970-1973) and had held high office in international institutions (International Monetary Fund, 1965-1969; European Monetary Institute, 19971999); Trichet had spent most of his career as a civil servant (mainly at the French Treasury, 1981-1985 and 1987-1993). In the private sector, Duisenberg was a Vice-President of Rodobank Nederland (the largest Dutch commercial bank) from 1978 to 1981, while Trichet's experience was more limited (from 1966 to 1968). As for politics, Duisenberg was steeped in politics (as a Labor Party member, a Member of Parliament (1977-1978), and Finance Minister (1973-1977)), Trichet had never had direct responsibilities. However he was an adviser to President Valéry Giscard d'Estaing (19781981), and to René Monory, Economy and Finance Minister (1978), and above all was Chief of Staff of the Prime Minister, Edouard Balladur (19861987). Classified as being on the right, he claims no partisan affiliation. 
As to their education, Duisenberg is an economist ( $\mathrm{PhD}$ in 1965) who presents himself as a moderate Keynesian, sensitive to the arguments of monetarism and neo-classical theory. Trichet originally trained as an engineer (diploma in 1964), but also has a degree in economics (1966) and training as a finance inspector (at ENA (École Nationale d'Administration) the prestigious institution which has a legal quasi-monopoly over entry to top positions in the French civil service), 1971). In educational terms, Trichet appears to be slightly more orthodox than Duisenberg. But when the whole range of elements relating to educational and professional background are combined, it is, at the very least, risky to differentiate between the two candidates in terms of their degree of conservatism.

Thus, the negotiations to appoint the ECB's first President were conducted with a background of divergences related to the personal and institutional conservatism of the candidates. The presumption that the French candidate is less strongly orthodox in monetary policy than the Dutch, results more from a simple transposition of his personality added to the degree of institutional conservatism of the Bank of France than from his own preferences. On this last aspect, only a retrospective analysis of their behavior as the ECB's President, allows their degree of personal conservatism to be differentiated.

\section{The degree of conservatism}

As ECB President, is Jean-Claude Trichet less aggressive than Wim Duisenberg? This section proposes, to answer this question, a measure of their degree of conservatism. Based on the performances of economic growth and inflation, this measure is drawn from the canonical version of the New Keynesian monetary model. This relies mainly on a New Keynesian Phillips curve, obtained in a setting with sticky prices and rational expectations of the agents ${ }^{11}$.

The New Keynesian Phillips curve establishes a positive relationship between the inflation rate and the output gap ${ }^{12}$, for a given level of forwardlooking expectations of the future inflation rate. Let us denote the value of the output gap at date $t$ by $x_{t}$, and the deviation of the inflation rate in $t$ from its long term value by $\pi_{t}{ }^{13}$. The canonical version of this relation, used in particular by Clarida, Gali and Gertler (1999), is expressed as:

\footnotetext{
11 For a complete presentation of this model and its generalizations see Woodford (2003).

12 The output gap is the percentage deviation of real GDP from its (efficient) potential level. Let us indicate by $y_{t}$ the real product and $z_{t}$ its potential level. The output gap can be defined by the logarithmic percentage $\ln \left(y_{t} / z_{t}\right)$ or by the "natural" percentage $\left(y_{t}-z_{t}\right) / z_{t}$. We use the second formulation in the rest of this paper.

13 If the (uncentred) inflation rate is $\pi_{t}^{u c}$ and the long term inflation rate is $\pi$, then $\pi_{t}=\pi_{t}^{u c}-\pi$.
} 


$$
\pi_{t}=\lambda x_{t}+\beta E_{t} \pi_{t+1}+u_{t}, \lambda>0, \beta>0,
$$

where $u_{t}$ is a shock ${ }^{14}$, observable by the Central Bank at the beginning, and where $E_{t}[$.$] indicates the conditional expectation of all available informa-$ tion at date $t$.

The Phillips' curve (1) is derived from an environment of sticky prices by Fischer (1977), Taylor (1980) and Calvo (1983). To briefly describe this environment, it is that of firms in monopolistic competition, where individual firms are observed to discretely adjust their prices at infrequent intervals of apparently stochastic length.

The New Keynesian version of the Phillips curve differs from the traditional version, known as the "augmented expectations" Phillips curve, by the substitution of forward-looking expectations $E_{t} \pi_{t+1}$ for backward-looking expectations $E_{t-1} \pi_{t}$. This substitution, which originates in the firms' behavior oriented towards the future, because of the constraint of the rigidity of prices that they encounter, is reflected in the practices of the Central Bankers. This has undoubtedly contributed to the success of the New Keynesian model.

The incorporation of such forward-looking expectations enables all the subtlety of the monetary policy to be captured in a simple model. The important thing is not so much to affect, by often modest changes of interest rate, the present decisions of agents, as to affect their expectations in a way which is favorable to the conduct of monetary policy. It is through the channel of expectations that the Central Bank increases its leverage on economic activity, starting from the modest initial influence of the interest rate on cost in economic agents' decisions.

We assume a welfare loss function $\left(V_{t}\right)$, which is the standard specification in the monetary policy literature:

$$
V_{t}=E_{t}\left\{\sum_{i=0}^{\infty} \beta^{i}\left[x_{t+i}^{2}+\alpha_{t} \pi_{t+i}^{2}\right]\right\}, \alpha_{t}>0 \forall t .
$$

According to Equation (2), the Central Bank's goal is to stabilize the trajectories of the output gap and the inflation deviation around zero. Parameter $\alpha_{t}$ represents the weight given to the stabilization of inflation relative to the output gap. It measures the Central Banker's degree of conservatism. If this parameter is indexed by $t$, this is because it can change from one Central Banker to another.

To minimize its loss function, the Central Bank does not undertake to follow any rules on interest rates. On the contrary, it acts at each period

14 This shock is not necessarily a white noise. Clarida et al. (1999) define it as a stationary first-order autoregressive process. 
in a completely discretionary way ${ }^{15}$, by setting the nominal value of the short-term interest rate. This interest rate affects the output gap according to an equation of the IS type, which then acts on the inflation deviation according to the Phillips' equation. Note that it is possible to obtain the first order condition without using the IS relation: it suffices to minimize Equation (2), relative to $x_{t}$ and $\pi_{t}$, under the only constraint given by the Phillips curve. To solve this problem, the Central Banker minimizes the quantity:

$$
\left[x_{t}^{2}+\alpha_{t} \pi_{t}^{2}\right]+F_{t}
$$

at each period, under the constraint:

$$
\pi_{t}=\lambda x_{t}+f_{t}
$$

where $F_{t} \equiv E_{t}\left\{\sum_{i=1}^{\infty} \beta^{i}\left[x_{t+i}^{2}+\alpha_{t} \pi_{t+i}^{2}\right]\right\}$ and $f_{t} \equiv \beta E_{t} \pi_{t+1}+u_{t}$ are fixed quantities, because of the supposed rationality of expectations. The solution of this minimization problem is:

$$
x_{t}=-\lambda \alpha_{t} \pi_{t} .
$$

Equation (5) defines the macroeconomic control that the Central Bank seeks to exert. In a period where inflation is above its long-term mean $\left(\pi_{t}>0\right)$, the Central Bank reduces the demand $\left(x_{t}<0\right)$ and conversely in periods of low inflation. Equation (5) tells us that the magnitude of the Central Bank's reaction depends positively on its degree of conservatism. When the Central Bank is more aggressive, then it is acting more conservatively. If, from one date to another, there is a difference in the Central Bank's aggressiveness, then we can conclude that the degree of conservatism has varied. This idea forms the basis of the methodology described below.

We assume that coefficient $\alpha_{t}$ is constant during the mandate of each Central Banker. In our analysis, it is possible to distinguish the Duisenberg period from the Trichet period. Let us label these periods $\tau=D$ and $\tau=T$. For each period $\tau$, the parameter $\alpha_{t}$ takes the constant value $\alpha_{t}$, and Equation (5) can be rewritten as

$$
x_{t}=-\lambda \alpha_{\tau} \pi_{t}
$$

what can also be written on average in each period $\tau$ as

$$
\bar{x}_{t}=-\lambda \alpha_{\tau} \bar{\pi}_{t}
$$

15 The ECB Executive Board members have, on various occasions, rejected the possibility of a planned action or organizing monetary policy according to a policy rule. The ECB's hostility to rate rules is evident in some of its publications (European Central Bank, 2001). 
where $\bar{x}_{\tau}$ and $\bar{\pi}_{\tau}$ are respectively the average output gap and the average inflation deviation over the period $\tau$. From Equation (7), the following measure of the degree of conservatism can be derived:

$$
\alpha_{\tau}=-\lambda^{-1} \frac{\bar{x}_{\tau}}{\bar{\pi}_{\tau}} .
$$

The fact that parameter $\lambda$ is unknown is not a problem, because $\alpha_{\tau}$ is proportional to $-\left(\bar{x}_{\tau} / \bar{\pi}_{\tau}\right)$. The degree of conservatism is larger when $\left(\bar{x}_{\tau} / \bar{\pi}_{\tau}\right)$ is low. This result has a strong intuitive content, over and above the framework of this model: the Central Banker is more even conservative than he is ready to reduce the demand $\left(\bar{x}_{\tau}<0\right)$ in periods of inflationary tension $\left(\bar{\pi}_{\tau}>0\right)$. To compare the two ECB presidencies Equation (8) can be rewritten as:

$$
\frac{\alpha_{T}}{\alpha_{D}}=\frac{\bar{x}_{T}}{\bar{x}_{D}} \frac{\bar{\pi}_{D}}{\bar{\pi}_{T}}
$$

This shows how changes in the output gap and inflation rate, from one period to another, reveal any modification of the Central Bank's preferences. If the average output gap grew faster as the average inflation rate decreased, then the Central Bank's degree of conservatism increased. Equation (9) can thus update changes in the aggressiveness of the Central Bank, implicitly included in the data on inflation and growth. It provides a simple measure of the variation in the degree of conservatism, and is useful in conditions where the two Central Bankers' reaction functions cannot be estimated or compared, given the small sample size.

More rigorously, Equation (5) stipulates that, conditional on the degree of conservatism, $x_{t}$ and $\pi_{t}$ are perfectly negatively correlated. Once possible variations of $\alpha_{t}$ are taken into account, the inflation rate and the output gap must be perfectly related, because of the strong control exerted by the Central Bank. It is of course unrealistic to believe that the Central Bank has the means of exerting such a perfect macroeconomic control. In fact, macroeconomic variables are resistant to any attempt at control ${ }^{16}$. However, the idea contained in Equation (5) remains tenable. It corresponds to the practice of Central Bankers, in the sense that when inflation is high, they reduce demand, and when inflation is low they do the reverse. Equation (5) is imperfectly checked, as is the control exerted by the Central Bank. It should be noted that the existence of such control is more likely over a long period than a short period: if the Central Bank can not affect the trajectory of a variable over a short period, it has much better control

16 Equation (5) does not claim that the Central Bank can control the inflation rate and output gap perfectly in a simultaneous way. If this were the case, it would always reach all its targets. Equation (5) is more modest: it simply states that the Central Bank exerts perfect control over the combination of these two variables. Even if such control seems moderate, it is greater than Central Bankers can actually exert. For a description of Central Bankers' practices see Blinder (1998). 
over a longer period. Equation (5) is more credible when it is defined on average over several years.

\section{$4 \quad$ Empirical application}

In order to distinguish the two chairmen's mandates, we chose the periods 1999-2003 for Duisenberg, and 2004-2008 for Trichet ${ }^{17}$. The annual data for the inflation rate and output gap in the euro area published by OECD $(2007)^{18}$, are presented in Table 2 . They allow us to calculate the average output gap over two successive periods: $\bar{x}_{D}=0.7$ and $\bar{x}_{T}=-0.9$.

\begin{tabular}{|l|c|c|c|c|c|c|c|c|c|c|}
\hline & $\mathbf{1 9 9 9}$ & $\mathbf{2 0 0 0}$ & $\mathbf{2 0 0 1}$ & $\mathbf{2 0 0 2}$ & $\mathbf{2 0 0 3}$ & $\mathbf{2 0 0 4}$ & $\mathbf{2 0 0 5}$ & $\mathbf{2 0 0 6}$ & $\mathbf{2 0 0 7}$ & $\mathbf{2 0 0 8}$ \\
\hline Inflation rate & 1.1 & 2.1 & 2.4 & 2.3 & 2.1 & 2.2 & 2.2 & 2.2 & 2.1 & 2.5 \\
\hline Output gap & 0.3 & 2.1 & 1.8 & 0.3 & -1.0 & -1.3 & -1.7 & -0.9 & -0.3 & -0.3 \\
\hline
\end{tabular}

Table 2: Inflation rate and output gap of the Euro area Source: OECD (2007)

During the Duisenberg period, the production of the euro area was above its potential level, whereas it remained below trend for the Trichet period. These two means by themselves cannot however allow us to draw any conclusions about the degree of conservatism of the two presidencies. The average deviation of inflation from the long term mean in the two periods, $\bar{\pi}_{D}$ and $\bar{\pi}_{T}$, must also be taken into account. Unfortunately, this inflation deviation cannot be calculated simply, the value of the long-term mean, $\pi$, being unknown ${ }^{19}$. From the inflation rates published by the OECD and presented in Table 2 , we can calculate that $\bar{\pi}_{D}^{n c}=2$ and $\bar{\pi}_{T}^{n c}=2.24$, connected to $\bar{\pi}_{D}$ and $\bar{\pi}_{T}$ by the relationships: $\bar{\pi}_{D}=\bar{\pi}_{D}^{n c}-\pi$ and $\bar{\pi}_{T}=\bar{\pi}_{T}-\pi c$

To apply Equation (9), the long-term inflation rate $\pi$ must be estimated. The mean of inflation rate of over all the periods studied ${ }^{20}$, $\pi=E\left(\pi_{t}^{n c}\right)$, which gives a value of 2.12 , is an unbiased estimator of this

17 The robustness of the results for the period setting is examined later, in particular to take into account the existence of transitional periods (years 1999 and 2004).

18 The euro area annual inflation data are calculated using the HPCl (Harmonized Consumer Price Index). As for the output, it is calculated using a methodology developed by OECD, and revised at the end of 2007.

19 If we assume that the Central Bank achieves its long-term inflation target, then the long-term inflation rate is equal to the target. However the ambiguity of various declarations from the ECB leaves room for doubt as to the value of its target. Is it a value lower than $2 \%$ (in which case what value exactly?), exactly $2 \%$, or a value close to $2 \%$ ? All these positions have been, at one time or another, defended by the ECB, so that it is not clear what its long-term objective is.

20 A change of Central Banker's preference, in the form of a variation the coefficient $\alpha_{t}$ mean that does not imply any variation of the value of the long term inflation rate. 
parameter. Unfortunately, even though $\bar{\pi}$ is generally a good estimator of $\pi$, it is not suitable to be used jointly with $\bar{\pi}_{D}^{n c}$ and $\bar{\pi}_{T}^{n c}$, because of the identity which binds these three parameters. However, the long-term inflation rate has another property which helps to estimate it: by definition, $\pi$ is the value of inflation rate associated with a zero output gap. According to Equation (5), we have $x_{t}=0 \Leftrightarrow \pi_{t}=0$, or $x_{t}=0 \Leftrightarrow \pi_{t}^{n c}=\pi$. It appears that the long-term rate $\pi$ can be estimated as the value of in the neighborhood of $x_{t}=0$. The closer the output gap is to zero, the more representative of the long term rate is the value of the inflation rate at that date.

The generalization of this principle leads us to suggest that a weighted mean of inflation rates can be used as an estimator of $\pi$, with the weighting being higher when the observation has an output gap close to zero. Below, we propose the calculation of an estimator based on a biweighted mean (Mosteller and Tukey, 1977), which takes the form:

$$
\bar{\pi}_{b p}=\frac{\sum_{t} w_{t} \pi_{t}^{n c}}{\sum_{t} w_{t}},
$$

where the weightings $w_{t}$ are given by:

$$
w_{t}=\left\{\begin{array}{cc}
\left(1-D_{t}^{2}\right)^{2} & \text { si }\left|D_{t}\right| \leq 1 \\
0 & \text { si }\left|D_{t}\right|>1
\end{array},\right.
$$

$D_{t}$ measures the proximity of the output gap of the observation t to the reference value zero

$$
D_{t}=\frac{x_{t}}{3 I Q R}
$$

where IQR is the interquartile range of $x_{t}$.

The application of Equation (10) to the data in Table 2 gives the value $\bar{\pi}_{b p}=2.11$, close to the simple mean ${ }^{21}$. Thus, the ECB seems to have conducted a slightly more inflationary policy than it sometimes claimed (a long-term inflation rate below $2 \%$ ). Using this value to calculate the longterm inflation rate, gives the average deviations of inflation over the two periods as $\bar{\pi}_{D}=-0.111$ and $\bar{\pi}_{T}=0.129$. These values indicate that inflation was higher than its long-term value after the change of ECB presidency, whereas it was lower than its long term value under the Wim Duisenberg. This is not sufficient, however, to show a lesser degree of conservatism on the part of Jean-Claude Trichet. These results have to be considered in the light of growth in the two periods.

Table 3 summarizes the four values on which our analysis concentrates, and shows the coherence of Equation (5). The negative relation between the output gap and the inflation deviation, predicted by Equation (5), is evident.

21 The similarity of the simple and the biweighted mean can be interpreted as a sign of the robustness of the estimated value. It seems that long-term inflation in the euro area is slightly above $2 \%$. 


\begin{tabular}{|l|l|l|}
\hline & \multicolumn{1}{|c|}{ Output gap } & \multicolumn{1}{c|}{ Inflation excess } \\
\hline Duisenberg & $\bar{x}_{D}=0.7$ & $\bar{\pi}_{D}=-0.111$ \\
\hline Trichet & $\bar{x}_{T}=-0.9$ & $\bar{\pi}_{T}=0.129$ \\
\hline
\end{tabular}

Table 3. Output gap and inflation deviation over the two periods

$\bar{x}_{\tau}$ : average output gap over the period $\tau ; \overline{\boldsymbol{\pi}}_{\tau}$ : average inflation deviation over the period $\tau$, with $\tau=D$ (Duisenberg period) and $\tau=T$ (Trichet period).

Source: Authors' calculations, from data in Table 2.

These figures show that it would have been unreasonable to conclude, simply from knowledge of the inflation rates, that there had been an easing of the monetary rigor during the transition from one presidency to the next. The inflation deviation during the Trichet period is certainly positive, but this is linked to a negative output gap. Faced with higher inflation than the long term value, Trichet acted to reduce demand. Similarly, although the inflation deviation was negative during the Duisenberg period, it was coupled to a positive output gap. Faced with inflation below its long-term value, Duisenberg supported demand.

Do these figures support the idea that the second President was less conservative than his predecessor? The application of the Equation (9) to the data in Table 3 gives $\frac{\alpha_{T}}{\alpha_{D}}=\frac{\bar{x}_{T}}{\bar{x}_{D}} \frac{\bar{\pi}_{D}}{\bar{\pi}_{T}}=1.10$. The degree of conservatism thus seems not to have decreased with the change in the ECB presidency, but to have remained relatively stable or even increased very slightly. If the significance of this slight increase is questionable, at least the thesis that Trichet was less conservative can be rejected. The results of Trichet's monetary policy, as compared with Duisenberg's, do not support the hypothesis that the change in the presidency led to less conservatism. Admittedly, the two presidencies were carried out in different macroeconomic contexts ${ }^{22}$, leading to inflation and growth results in apparent opposition according to Table 3. However, these results suggest that the degrees of conservatism were similar.

Is the empirical analysis which supports this conclusion robust? The question may arise for three different reasons. First, the data for the year 2008 are less reliable because they are partially predicted and may, in the future, undergo significant revision. Second, it may not be advisable to include the year 1999. This year is atypical and can be considered to be an outlier; in addition, considering the periods of monetary policy action, the macroeconomic performance of 1999 may not be the result of ECB monetary policy, given that the first President had just arrived. Lastly, taking

22 The New Keynesian model, which is used as a basis for the methodology presented in this paper, does not suppose the stability of the macroeconomic context, since the equation of Phillips is affected of a shock $u_{t}$ which can take very different values according to periods. 
into account the existence of a time lag between the action and the result of monetary policy, perhaps the results for 2004 should be attributed to the first presidency rather than to the second.

We have recalculated the data using the same methodology, using three different configurations: 1) by removing the data for 2008; 2) by removing the data for 1999; 3) by integrating the data for 2004 into the first presidency. The application of Equation (9) gives the following results: $\frac{\alpha_{T}}{\alpha_{D}}=\frac{\bar{x}_{T}}{\bar{x}_{D}} \frac{\bar{\pi}_{D}}{\bar{\pi}_{T}}$ takes the values 0.96 in 1); 2.34 in 2) and 1.21 in 3 ). In other words, the results are variable. However, our conclusion stands, as the results never indicate a substantially less conservative approach in the second presidency. If we remove the year 2008, the degree of conservatism seems to be essentially the same in the two presidencies. If the 1999 results are ignored it seems to have increased substantially in the second period, whereas if the 2004 figures are attributed to Duisenberg's presidency the conservatism appears to have increased very slightly when he left. The methodology developed here leads us to reject the idea that there was any easing in the ECB's position during the transition between the two presidents. These results give no sign that Trichet's degree of conservatism was significantly lower than Duisenberg's.

\section{Conclusion}

This article has developed a measure of variation of the Central Banker's degree of conservatism. Applied to the data available, the results lead to a rejection of the hypothesis that there was a decrease in the degree of conservatism between the mandates of the ECB's first two presidents. In fact, Jean-Claude Trichet's aversion to inflation is no lower than that of his predecessor, Wim Duisenberg. These results suggest that the political compromise at the basis of Duisenberg and Trichet's appointments to the Presidency of the ECB was unnecessary. This compromise was based on the presumption that Duisenberg's aversion to inflation would be, in the Bundesbank tradition, stronger than Trichet's, in the tradition of the Bank of France before 1994.

The first explanation of our results lies in the fact that the two men were perhaps not as different as they were portrayed. The analysis of their personal preferences on inflation, from their professional and training background, casts doubt on the idea that Trichet would be less conservative than Duisenberg. The more marked political commitment of the Dutchman, as a Member of Parliament and then Minister of Finance, would actually suggest the opposite. It thus seems that the presumption which underpinned the political compromise, leading to the mid-term change in the 
ECB Presidency, has no basis other than the attribution to Trichet of the degree of institutional conservatism of the Bank of France, which before 1994 was indeed lower than that of the Nederlandsche Bank.

A second explanation for this result, related to the preceding one, is based on the Central Bankers' bureaucratic behavior. Appointed by the politicians, they cannot ignore the constraints they face. So, even if Duisenberg and Trichet had different preferences (which does not seem to be the case), perhaps was it difficult to express them in the institutional framework of the European System of Central Banks (ESCB). As Presidents of their national Central Banks and then of the ECB, their practices appear to have been marked more by the seal of pragmatism that by the dogmatism of partisan affiliation.

These explanations help explain why Trichet does not appear to be less conservative than Duisenberg. But, given that, according to our results, the degree of conservatism of the ECB's behavior may have increased slightly during his tenure, they do not provide an explanation for the actual patterns in the data.

Knowing himself expected to relax the monetarist orthodoxy, did Trichet stick to it in order not to undermine the ECB's credibility? It is a plausible explanation. Beyond the arguments relating to political logic and/ or the bureaucratic behavior of the Central Banker, a simple explanation can be found in Brainard's (1967) study of the prudence of Central Bankers in an uncertain situation. Do not forget that Duisenberg inherited the difficult task of directing a newly created supranational Bank, and thus he was forced to undergo the difficulties of creating a new European monetary policy. Without any history of macroeconomic reactions to a single currency in the euro area, Duisenberg was in a situation of relatively high uncertainty about the transmission mechanisms of monetary policy and the value of its parameters. However, Brainard (1967) argued that the appropriate behavior for a Central Banker in situation of uncertainty, was prudence ${ }^{23}$, characterized by a measured response to macroeconomic shocks ${ }^{24}$. In a situation where the effects of monetary policy are uncertain, the Central Banker is bound to be less aggressive.

Although Brainard's (1967) principle of prudence has been disputed in some recent models ${ }^{25}$, Central Bankers give it a real legitimacy in the practice of their profession ${ }^{26}$. It seems reasonable to think that Wim Duisenberg, on whom the task of identifying the value of the monetary policy's parame-

23 Brainard (1967) also used the term 'conservatism' to indicate this prudence, a meaning different from that which it is given in this paper.

24 See Le Bihan and Sahuc (2002) for an overview of the theory of monetary policy in an uncertain situation.

25 For instance, Bertocchi and Spagat (1993) suggested that the optimal monetary policy in an uncertain situation could be more activist, in order to try out the unknown monetary model and to generate some information.

26 For instance, Blinder (1997), writing as Deputy-Governor of the U.S. Federal Reserve, indicates that Brainard's prudence principle appears wise to him. 
ters of transmission fell, had to behave in a much less activist and aggressive way than he would have wanted. Thereafter, Jean-Claude Trichet could exploit the information gained from his predecessor's experiments and follow a more assured, and consequently perhaps more conservative, policy.

\section{References}

Acheson K. and J.F. Chant (1973), "Bureaucratic Theory and the Choice of Central Bank Goals: The Case of The Bank of Canada", Journal of Money, Credit and Banking, Vol. 5, No. 2, pp 637-655.

Aubin C. and J.D. Lafay (1995), "Objectifs Politiques et Contraintes Institutionnelles dans les Décisions de Politique Monétaire", Revue Economique, Vol. 46, No. 3, pp. 869-878.

Bade R. and M.J. Parkin (1985), Central Banks Laws and Monetary Policy, London: University of Western Ontario, Department of Economics.

Berthelot J. (1997), "Pas de Monnaie unique sans un minimum de Fédéralisme", in: Collectif (eds), La monnaie unique en Débat, Paris: La Découverte et Syros, pp. 85-109.

Bertocchi G. and M. Spagat (1993), "Learning, Experimentation, and Monetary Policy", Journal of Monetary Economics, Vol. 32, No.1, pp. 169-183.

Bezoen S. and P. Maier (2004), "Bashing and Supporting Central Banks: The Bundesbank and the European Central Bank", European Journal of Political Economy, Vol. 20, No.4, pp. 923-940.

Blinder A.S. (1997), "What Central Bankers Could Learn from Academics - and Vice Versa", Journal of Economic Perspective, Vol. 11, No.2, 3-19.

Blinder A.S. (1998), Central Banking in Theory and Practice, Cambridge: The MIT Press.

Brainard W.C. (1967), "Uncertainty and Effectiveness of Policy", American Economic Review, Vol. 57, No.2, pp. 411-425.

Calvo G. A. (1983), "Staggered Prices in a Utility-Maximizing Framework", Journal of Monetary Economics, Vol. 12, No.3, pp. 383-398.

Clarida R., J. Gali and M. Gertler (1999), "The Science of Monetary Policy: A New Keynesian Perspective", Journal of Economic Literature, Vol. 37, No.4, pp. 1661-1707.

Downs A. (1967), Inside Bureaucracy, Boston: Little Brown.

European Central Bank (2001), "Issues Related to Monetary Policy Rules", Monthly Bulletin, October, pp. 37-51.

Fischer S. (1977), "Long-Term Contracts, Rational Expectations, and the Optimal Money Supply Rule", Journal of Political Economy, Vol. 85, No.1, pp. 191-205.

Frey B.S. and F. Schneider (1981), "Central Bank Behavior: A Positive Empirical Analysis", Journal of Monetary Economics, Vol. 7, No.3, pp. 291-315.

Göhlmann S. and R. Vaubel (2005), "The Educational and Occupational Background of Central Bankers and its Effect on Inflation - An Empirical Analysis", European Economic Review, Vol. 51, No.4, pp. 925-941. 
Gordon R. J. (1975), "The Demand for and Supply of Inflation", Journal of Law and Economics, Vol. 18, No.3, 807-836.

Haan J. de, J.-E. Sturm and P. Maier (2002), "Political Pressure on the Bundesbank: An Empirical Investigation using the Havrilesky Approach", Journal of Macroeconomics, Vol. 24, No.1, pp. 103-123.

Havrilesky T. (1990), "The Influence of the Federal Advisory Council on Monetary Policy", Journal of Money, Credit and Banking, Vol. 22, No.1, pp. 37-50.

Hayo B. (1998), "Inflation Culture, Central Bank Independence and Price Stability", European Journal of Political Economy, Vol. 14, pp. 241-263.

Hibbs D. A. (1977), "Political Parties and Macroeconomic Policy", The American Political Science Review, Vol. 71, No.4, pp. 1467-1487.

Knaap T. and P. Maier (2002), "Who Supported the Deutsche Bundesbank?", Journal of Policy Modeling, Vol. 24, No.9, pp. 831-851.

Le Bihan H. and J-G. Sahuc (2002), "Règles de politique monétaire en présence d'incertitude: une synthèse", Revue d'Economie Politique, Vol. 112, No.3, pp. 349-386.

Lichfield J. (2003), "Trichet Set to Take Top Job at ECB", The Independent, 19 June 2003.

Masciandaro D. and G. Tabellini (1988), "Monetary Regimes and Fiscal Deficits: A Comparative Analysis" in: H. Cheng (ed), Monetary Policies in Pacific Basin Countries, Boston: Kluwer, pp. 125-152.

Mosteller F. and J.W. Tukey (1977), Data Analysis and Regression: A Second Course in Statistics, Reading, Mass.: Addison-Wesley.

OECD (1989), OECD Economic Outlook, Vol. 46, December.

OECD (1995), OECD Economic Outlook, Vol. 58, December.

OECD (2000), OECD Economic Outlook, Vol. 68, December.

OECD (2007), OECD Economic Outlook, Vol. 82, December.

Odent B. (1998), "BCE: la guerre des banquiers centraux", Frankfurter Allgemeine Zeitung, 29 April 1998.

Quatremer J. (2008), "BCE, mon amour", Libération, No.8346, 6 March, pp. 32.

Quatremer J. and T. Klau (1999), Les hommes qui ont fait l'euro, Paris: Plon.

Taylor J. B. (1980), "Aggregate Dynamics and Staggered Contracts", Journal of Political Economy, Vol. 88, No.1, pp. 1-24.

Toma E.F. and M. Toma (1986), Central Bankers, Bureaucratic Incentives, and Monetary Policy, Boston: Kluwer.

Vaubel R. (1997), "The Bureaucratic and Partisan Behavior of Independent Central Banks: German and International Evidence", European Journal of Political Economy, Vol. 13, pp. 201-224.

Vaubel R. (2003), "The Future of the Euro - A Public Choice Perspective" in: F. Capie and G.E. Wood (eds.), Monetary Unions: Theory, History, Public Choice, London and New York: Routledge, pp 146-181.

Woodford M. (2003), Interest and Prices, Foundations of a Theory of Monetary Policy, Princeton and Oxford: Princeton University Press. 